DOI: 10.12731/2218-7405-2018-7-36-62

УДК 314.7

\title{
ОБРАЗ СОЦИАЛЬНО-ПСИХОЛОГИЧЕСКОГО ПРОСТРАНСТВА ГОРОДА В ПРЕДСТАВЛЕНИИ МОЛОДЕЖИ С РАЗНЫМИ МИГРАЦИОННЫМИ НАМЕРЕНИЯМИ (НА ПРИМЕРЕ ГОРОДА КОМСОМОЛЬСКА-НА-АМУРЕ)
}

\author{
Бакина А.В., Орлова О.А., Яремчук С.В.
}

Тема, цель работы. Основной темой намего исследования выступали особенности эмоционального отношения к людям, объектам и явлениям социально-психологического пространства города 2. Комсомольска-на-Амуре у молодежи с разными миграционными намерениями.

Метод и методологию проведения работы. В исследовании приняли участие 130 жителей города в возрасте 16-25 лет, разделенные на три группь: не собирающиеся менять место жительства, намеренные уехать из города при первой возможности и допускающие возможность переезда при определенньх условиях. Для оченки эмочионального отночения к различным объектам социально-психологического пространства и изучения его структуры респондентам был предложен проективный модифицированный психогеометрический тест С. Деллингер. Исследование выстроено по типу репертуарной решетки, объектами оченки для респондентов выступали различные структурные компоненты социальнопсихологического пространства: коммуникативная сфера, возможности профессиональной и личностной самореализации, временные перспективы и территориальная идентичность испытуемых.

Результаты и выводы. Анализ результатов показал, что молодежь с выраженными миграционными намерениями более негативно относится к Дальневосточному региону, его населению и своей настоящей жизни. Данная группа молодежи пространство города рассматривает как неэффективное для самореализации и 
саморазвития в настоящем и будущем и не идентифищирует себя с территорией проживания. Молодежь, которая хочет остаться в городе, рассматривает его как эффективное пространство для самореализации и саморазвития, имеет сформированную территориальную идентичность, позитивно относится к своей настоящей жизни, месту проживания и населению города.

Область применения результатов. Результаты исследования могут быть применены в сфере проектирования сочиальной инфраструктуры, планирования молодежной и мигращионной политики при реализации «Стратегии социально-экономического развития мунищипального образования городского округа «Город Комсомольск-на-Амуре» до 2032 года».

Ключевые слова: сочиильно-психологическое пространство; миграционные намерения; молодежь; эффективность сочиальнопсихологического пространства города.

\section{SOCIO-PSYCHOLOGICAL SPACE OF KOMSOMOLSK-ON-AMUR AMONG YOUNG PEOPLE WITH DIFFERENT MIGRATION INTENTIONS}

\section{Bakina A.V., Orlova O.A., Yaremtchuk S.V.}

The article presents a research of the structure of the socio-psychological space of Komsomolsk-on-Amur among young people with different migration intentions. 130 16-25 year-old residents from Komsomolsk-on-Amur took part in this research. They were divided into three groups: those who were going to change their place of residence, those who intended to leave the city at the first opportunity and those who allowed for the possibility of moving under certain conditions.

To assess attitude of young people toward different socio-psychological space and to study its structure, a projective modified psychological geometric test by $S$. Dellinger was used. The study is presented in the form of a repertory grid. The objects of assessment for the respondents were various aspects of the socio-psychological space, which characterized its 
communicative sphere, possibility of professional and personal self-realization, temporarily prospects and territorial identity of the subjects.

The analysis of the results showed that young people with certain migration intentions had more negative attitude to the Far East region, its population and their own real life. This group of young people considers the space of the city as inefficient for self-realization and self-development in the present and future and does not identify itself with the territory of residence.

Young people who want to stay in the city, consider it as an effective space for self-realization and self-development. They have a formed territorial identity, positive attitude to their real life, to the place of residence and the population of the city.

The results of the research can be applied in the field of youth policy design.

Keywords: socio-psychological space; migration intentions; youth; efficiency of socio-psychological space of the city.

\section{Введение}

Социальные и экономические изменения современного мира вызвали интенсификацию процессов миграции. Данное явление, с одной стороны, неизбежно и желательно для решения экономических, демографических и других проблем территорий и самих субъектов переселения. С другой стороны, миграционные процессы несут проблемы и противоречия: одни регионы решают свои проблемы, а другие опустошаются («западный дрейф населения»), что вызывает острые дискуссии в обществе. Дальневосточный федеральный округ отличается среди всех других округов России самыми неблагоприятными тенденциями миграционных процессов, что крайне негативно влияет на развитие данного региона. По этой причине изучение миграционной активности молодежи Дальневосточного региона актуально для прогноза развития и управления миграционными процессами.

Дальний Восток существует в условиях целого ряда объективных негативных факторов: экстремальные природно-климатические 
условия, слабая освоенность и отдаленность региона от промышленно-развитых районов страны, труднодоступность большей части территории, бездорожье [24]. Перечисленные выше факторы негативно сказываются и на народонаселении, Дальневосточный федеральный округ отличается от всех других округов России самыми неблагоприятными тенденциями миграционных процессов, что крайне негативно влияет на развитие данного региона [6; 10; $17 ; 21]$. Поэтому не случайно, что на столь обширной территории Дальневосточного федерального округа сегодня проживает меньше человек, чем в Москве. Для разворота этой негативной тенденции или хотя бы её стабилизации необходимо понимать сдерживающие и выталкивающие характеристики социально-психологического пространства жизни для молодёжи Дальнего Востока.

Научная литература, посвященная изучению миграции, сконцентрирована в большей степени на построении экономических моделей миграционных процессов, основанных на экономическом благополучии районов, разнице в экономических возможностях между разными странами и районами, доходами населения в разных регионах. Особый интерес представляют исследования провинциальных районов, из которых жители стремятся уехать в центральные регионы и большие города [5; 10; 30]. Основная причина миграции из провинциальных районов (регионов) в крупные экономические центры связана, по мнению исследователей, с тем, что крупные города имеют диверсифицированные рынки труда, обеспечивающие относительно высокий уровень заработной платы. Развитая социальная инфраструктура обеспечивает более высокий уровень жизни $[8 ; 9 ; 11 ; 16 ; 17 ; 21]$.

В качестве основных мотивов миграции в исследованиях выделяют мотивацию власти и достижения [26], стремление к карьерному росту [31; 34; 39], улучшение своего образования, расширение диапазона возможных развлечений [38]. Исследователи, изучающие мотивы миграции, основываются на положении о том, что решение об изменении места жительства принимается в случае, когда люди считают, что могут в большей степени реализовать свои мотивы в 
другой стране или в другом регионе $[19 ; 21 ; 26]$. Экономические мотивы не являются приоритетными в решении о миграции для молодежи, которая стремится к переходу к взрослой жизни, соответствующей ее ожиданиям и ценностям.

Многократно изучались социальные связи человека как фактор миграции, было обнаружено, что межличностные отношения могут выполнять как сдерживающую, так и мотивирующую функцию в принятии решения о миграции $[25 ; 28 ; 29 ; 32 ; 36 ; 37]$. Близкие связи с людьми в месте проживания, наличие семьи, друзей, высокая ценность имеющихся отношений оказываются факторами, сдерживающими миграционную активность, в то время как наличие семьи и друзей за рубежом или в других регионах побуждает человека обдумывать решение о переезде. Также обнаружено, что знакомые в местах возможной эмиграции становятся источником надёжной информации для осознанного принятия решения [7; 13].

Современные исследования концентрируются на изучении таких информационных факторов, как доступ к знаниям о жизни в другой местности (в другой стране, городе или регионе) и представления людей о мигрантах и миграции. В частности, было установлено, что на возникновение миграционных намерений и принятие решения о переезде влияют социальные сети и знакомство с мигрантами [2; 35]. Исследования [33] показывают, что молодые люди, намеренные мигрировать, считают себя достаточно осведомленными о миграции, лучше относятся к феномену миграции в целом, а также имеют положительный образ мигранта, который может быть как продуктом их воображения, так и представлением, приобретенным в личном контакте.

Исследования последних лет показывают, что гораздо большая доля миграционных процессов объясняется психологическими причинами, нежели экономическими, так как люди могут оставаться даже в регионах с низким уровнем дохода и уезжать из экономически благополучных мест. Поэтому мы считаем, что миграционные намерения (установки) необходимо рассматривать в контексте проблемы «социально-психологического пространства города». 
Термины «психологическое» и «социальное» пространство в социологических и психологических работах имеют давнюю традицию (А. Адлер, Э. Богардус, Г. Зиммеля, К. Левин, П. Сорокин, С.Л. Рубинштейн, Т.Ф.Е. Василюк, Д.А. Леонтьев, В.И. Слободчиков и др.). Предметом современных психологических исследований часто становится множество «...психологических пространств существования человека, как общих, универсальных, так и частных, специализированных видов пространства, выделяемых в результате анализа взаимодействия субъекта с конкретными сферами жизнедеятельности человека...» [3].

Г.В. Щукова [25] понятие социально-психологическое пространство относит к «молодым» (на современном этапе развития науки), в исследованиях оно чаще всего позиционируется через указание и перечисление разнообразных областей жизнедеятельности человека. В числе важной характеристики социально-психологического пространства выделяют его многоаспектный характер: оно включает социальные и персональные поля, пространственные и временные параметры [14]. Поскольку человек является активным субъектом жизнедеятельности, он создает систему позитивно, нейтрально или негативно значимых объектов или явлений (включая его самого) социальной среды. Значимые объекты или явления могут как существовать, так и не существовать в реальном окружающем мире; восприниматься разными людьми принципиально различным образом и выполнять в их жизни совершенно особые функции [3; 4]. Поэтому одни и те же объективные обстоятельства могут по-разному отражаться и означаться субъектом. Следующая особенность заключается в том, что элементы пространства занимают в нем определенное место, «объем», образуя зоны или сферы отношений, которые отличаются не только психологической близостью или удаленностью от субъекта, но и своим положением по различным направлениям (ориентацией по разным «координатным осям» пространства).

Не пытаясь рассмотреть все многообразие определений понятия «социально-психологическое пространство», а также разные подхо- 
ды к его анализу, отметим самое существенное для нашего исследования. Под социально-психологическим пространством города мы понимаем множество субъективно сформированных горожанами отношений к значимым людям (в том числе и к себе), группам или явлениям городской жизни. Множество этих субъективных отношений находятся в специфических связях друг с другом. В своем исследовании мы акцентировали внимание на эмоционально окрашенных отношениях субъекта. Поскольку центральными задачами молодежной возрастной группы являются формирование социальной и профессиональной идентичности, жизненных планов, в структуру социально-психологического пространства города были включены специфические для данного возраста сферы и явления: коммуникативная, профессиональная и личностная сферы, временные перспективы и территориальная идентичность.

В современных исследованиях социально-психологическое пространство рассматривают как среда, в которой происходит формирование и развитие личности, ее социализация. Все чаще данный феномен используют в качестве объяснительной модели процессов самоорганизации и саморазвития человека $[14 ; 18 ; 20 ; 25]$. По мнению А.Л. Журавлева и А.Б. Купрейченко, при анализе социально-психологического пространства в контексте изучения самоопределяющегося субъекта важна также оценка и по критерию его влияния на успешность самоопределения или на эффективность жизнедеятельности, с точки зрения самого субъекта. Такими $x a-$ рактеристиками эффективности пространства могут выступать различные критерии: комфортность/некомфортность, гармоничность/негармоничность, безопасность/опасность, бесконфликтность/конфликтность и т.д. [3, 4, 14]. Социально-психологическое пространство может получить и совокупную оценку по критерию его влияния на успешность самоопределения или эффективность жизнедеятельности, с точки зрения самого субъекта. В этом случаи эффективность чаще всего трактуется как достижение поставленных целей с наименьшими затратами времени и ресурсов, т.е. оценка субъектом возможностей реализовать свои потребности, 
интересы и цели в предлагаемых условиях. В своем исследовании мы будем оценивать эффективность социально-психологического пространства города с точки зрения возможностей самореализации субъекта в пределах места проживания.

По нашему мнению, миграционная установка базируется на индивидуальной системе оценки возможностей для самореализации социально-психологического пространства города. Место проживания мы анализируем не как географический объект, а как социально-психологическое пространство жизнедеятельности, наполняемое личностным смыслом и воспринимаемое субъектом как условие, способствующее или препятствующее реализации значимых мотивов и целей. Основанием для сравнения являются возможности, которые предоставляют различные места проживания (города, регионы, страны) для самореализации, а результат сравнения, в свою очередь, влияет на миграционное поведение.

Целью исследования является изучение эмоционального отношения к людям, объектам и явлениям социально-психологического пространства города у молодежи с разными миграционными намерениями (на примере города Комсомольска-на-Амуре).

В исследовании проверялась следующая гипотеза: существуют значимые различия в широте круга общения, эмоциональном отношении к различным объектам социально-психологического пространства у молодежи с разными миграционными намерениями.

Задачами исследования выступали: 1) изучить миграционные намерения молодежи города Комсомольска-на-Амуре; 2) выявить значимые различия в широте круга общения у молодежи с разными миграционными намерениями; 3 ) выявить отношения к различным объектам социально-психологического пространства у молодежи с разными миграционными намерениями.

\section{Материалы и методы}

В исследовании приняли участие 130 испытуемых, молодые люди в возрасте 16-25 лет (средний возраст 23,1 года), жители г. Комсомольскана-Амуре. Исследование проходило в 2016-2017 годах. 
На первом этапе исследования с помощью анкеты были изучены миграционные намерения молодежи г. Комсомольска-на-Амуре. Для изучения миграционных намерений респондентам было предложено ответить на прямой вопрос: «Собираетесь ли Вы уезжать из города?». В зависимости от ответа все респонденты были разделены на три группы, условно обозначенные нами как «патриоты» (не собираются менять место жительства), «антипатриоты» (намерены уехать из города) и «прагматики» (указали, что могут уехать при определенных условиях).

Для исследования круга общения молодежи в анкету были включены вопросы о числе друзей в реальной жизни и социальных сетях.

Для оценки эмоционального отношения к различным объектам социально-психологического пространства и изучения его структуры респондентам был предложен проективный модифицированный психогеометрический тест С. Деллингер [15]. Исследование выстроено по типу репертуарной решетки. Объектами оценки для респондентов выступали следующие аспекты социально-психологического пространства: коммуникативная сфера (друзья, семья, мы); профессиональная и личностная самореализация (работа, профессиональная карьера, самореализация, образование, возможности); временные перспективы (будущее, настоящее) и территориальная идентичность (комсомольчанин, Комсомольск-на-Амуре, Дальний Восток, «Они»). Категория «Я» служит для обозначения говорящим самого себя.

Отношение к предложенным явлениям определялось рангом категории в ряду предпочтения психогеометрических фигур, ассоциирующихся с данным явлением. Более высокий ранг указывает на более негативное отношение субъекта к данному явлению и наоборот. Шкала оценки варьирует от одного до пяти баллов, где 1 - максимально положительное отношение, 5 - максимально отрицательное отношение.

Для оценки связи между объектами социально-психологического пространства города использовали коэффициент ранговой корреляции Спирмена ( $\rho)$. Значимость различий между выборками определялась с помощью критерия Манна-Уитни с использованием программы STATISTICA 10. 


\section{Результаты и обсуждение}

Миграционные намерения молодежи города. Результаты исследования показали, что 26\% молодых людей не собираются менять место жительства, 22\% респондентов заявили, что намерены уехать из города, $52 \%$ молодежи указали, что могут уехать при определенных условиях. Полученные результаты схожи с данными Сигаревой Е.П., Сивоплясовой С.Ю., полученными на молодежной выборке. В процессе опроса молодежи о миграционных намерениях они выявили три группы респондентов: «прагматики», «патриоты» и «антипатриоты». Опрос зафиксировал, что в общей совокупности респондентов значительную часть составляют «прагматики», то есть те, чьи намерения не связаны с определенной территорией, а обусловлены наличием благоприятных условий [23]. Большая часть (52 \%) молодых комсомольчан также входят в условную группу «прагматиков», т.е. они не исключают возможности своей жизни в городе, но при определенных условиях.

Поскольку при изучении миграционных процессов неоднократно отмечалась важность общения с другими людьми, которое может выступать как сдерживающим, так и стимулирующим фактором смены места жительства, в нашем исследовании осуществлялось сравнение интенсивности реального и виртуального общения молодежи с разными миграционными намерениями (таблица 1).

Таблиияа 1.

Средние показатели интенсивности общения разных групп молодежи,

и их сравнительная характеристика

\begin{tabular}{|c|c|c|c|c|c|c|}
\hline \multirow{2}{*}{ Показатели } & \multicolumn{3}{|c|}{$\begin{array}{c}\text { Средние показатели } \\
\text { по группам }\end{array}$} & \multicolumn{3}{|c|}{$\begin{array}{c}\text { Значение коэффициент } \\
\text { Манна-Уитни (U) }\end{array}$} \\
\cline { 2 - 7 } & $\begin{array}{c}\text { «Антипа- } \\
\text { триоты» (1) }\end{array}$ & $\begin{array}{c}\text { «Патрио- } \\
\text { ты» (2) }\end{array}$ & $\begin{array}{c}\text { «Прагма- } \\
\text { тики» (3) }\end{array}$ & $\begin{array}{c}\text { между } \\
\mathbf{1} \text { и 2 }\end{array}$ & $\begin{array}{c}\text { между } \\
\mathbf{1} \text { и 3 }\end{array}$ & $\begin{array}{c}\text { между } \\
\mathbf{2} \text { и 3 }\end{array}$ \\
\hline $\begin{array}{c}\text { Реальные } \\
\text { друзья }\end{array}$ & 2,3 & 2,4 & 2,3 & 471,5 & 1168,0 & 898,0 \\
\hline $\begin{array}{c}\text { Общение в } \\
\text { социальных } \\
\text { сетях }\end{array}$ & 2,1 & 1,7 & 1,9 & $\mathbf{3 6 4 , 0 *}$ & 1003,0 & 893,5 \\
\hline
\end{tabular}

Примечание.

* - значимые различия между выборками по критерию Манна-Уитни (для $\mathrm{p} \leq 0,05$ ) 
Интенсивность общения в реальной жизни у всех выделенных групп примерно одинаковая, а активность в социальных сетях имеет значимые различия: молодежь, которая хочет уехать из города более интенсивно общается, чем группа «патриотов» $(\mathrm{U}=364$, значимо для $\mathrm{p} \leq 0,05)$. Видимо, молодые люди использует социальные сети для общения со сверстниками из других регионов или знакомыми, сменившими место жительства (например, учатся в другом городе), которые часто высказывают гипертрофированные и даже ложные оценки о полученных выгодах, выкладывают красивые фотографии и т.д., не акцентируя внимания на минусах переезда и проблемах адаптации. Это формирует у молодых людей завышенные ожидания от миграции и усиливает мотивацию на переезд.

Л. Фестингер считает, что в ситуациях отсутствия объективных стандартов индивиду требуется социальное сравнение для оценки своего положения, и в этом случае он прибегает к сравнению себя с похожими на него людьми [27]. В современном обществе люди для познания и получения информации часто используют не собственный опыт, а опыт других людей, который они получают через глобальные информационные системы.

Отночение к социально-психологическому пространству города Комсомольска-на-Амуре у молодежи с разными миграционными намерениями. В данном исследовании место жительства мы анализируем не просто как географический объект, а как пространство жизнедеятельности, которое наполняется личностным смыслом и приобретает эмоциональную окраску. Результаты изучения эмоционального отношения респондентов к различным аспектам жизни в городе у разных групп молодежи представлены в таблице 2 .

Для всех групп молодежи характерно наиболее позитивное отношение к самим себе и категориям, отражающим межличностные отношения: своим друзьям, семье и группе, к которой они себя относят (категория «Мы»).

Наиболее негативное отношение «антипатриоты» и «прагматики» демонстрируют к категориям территориальной идентичности 
(Комсомольску-на-Амуре, его жителям, Дальнему Востоку в целом) и своему настоящему. В отличие от них, негативное отношение к предложенным категориям у молодежи, не стремящейся покинуть город, выражено в меньшей степени, чем у двух остальных групп. Наиболее негативно «патриоты» оценивают аутгруппу (категория «Они»), свое образование. Они более позитивно относятся к категориям «Мы» и «Настоящее»: значимо лучше относятся к ингруппе, чем «антипатриоты» $(\mathrm{U}=365$, при $\mathrm{p} \leq 0,05)$ и значимо лучше оценивают свое настоящее, чем «прагматики» $(\mathrm{U}=695,5$, при $\mathrm{p} \leq 0,05)$.

Таблицуа 2.

Средние значения рангов отношения молодежи к различным жизненным явлениям

\begin{tabular}{|c|c|c|c|}
\hline \multirow{2}{*}{ Категории } & \multicolumn{3}{|c|}{ Средние показатели по группам } \\
\hline & «Антипатриоты» & 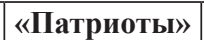 & «Прагматики» \\
\hline \multicolumn{4}{|c|}{ Коммуникативная сфера } \\
\hline Я & 1,7 & 1,9 & 1,9 \\
\hline Друзья & 1,9 & 2,5 & 2,5 \\
\hline Семья & 2,1 & 2,0 & 2,1 \\
\hline Мы & $2,5^{*}$ & $1,8^{*}$ & 2,1 \\
\hline \multicolumn{4}{|c|}{ Профессиональная и личностная самореализация } \\
\hline Работа & 2,9 & \begin{tabular}{|l|}
2,8 \\
\end{tabular} & 2,9 \\
\hline Профессиональная карьера & 2,6 & 2,9 & 2,8 \\
\hline Самореализация & 2,9 & 2,7 & 2,6 \\
\hline Образование & 2,9 & 3,0 & 2,9 \\
\hline Возможности & 2,9 & 2,8 & 2,9 \\
\hline \multicolumn{4}{|c|}{ Временные перспективы } \\
\hline Будущее & 3,0 & 2,7 & 3,2 \\
\hline Настоящее & 3,1 & $2,6^{*}$ & $3,3^{*}$ \\
\hline \multicolumn{4}{|c|}{ Территориальная идентичность } \\
\hline Комсомольчанин & 3,1 & 2,8 & 3,1 \\
\hline Комсомольск-на-Амуре & 3,4 & 2,9 & 3,1 \\
\hline Дальний Восток & 3,1 & 2,9 & 3,2 \\
\hline Они & 3,2 & 3,3 & 3,6 \\
\hline
\end{tabular}

Примечание.

* значимые различия между выборками по критерию Манна-Уитни (для $\mathrm{p} \leq 0.05$ )

Таким образом, для молодежи, стремящейся уехать, является характерным негативное отношение к региону и его населению и 
своей настоящей жизни, что является отражением их миграционной установки и предпосылкой для намерения сменить место жительства. Для молодежи, желающей остаться в регионе, предложенные категории в целом оказываются более позитивно окрашенными, в том числе их настоящее, место проживания и население города.

На рисунках 1, 2, 3 представлены результаты корреляционного анализа отношения молодежи к предложенным категориям. Представленные в рисунках категории расположены по эмоциональному отношению к ним респондентов: в верхней части располагаются самые позитивно оцениваемые, а в нижней - с самыми негативными оценками. Анализ полученных данных осуществлялся в соответствии с основными структурными составляющими социально-психологического пространства: содержание и структурность (жизненные явления и значимые связи между ними); временная перспектива (настоящее и будущее, связанные с ними явления); территориальная идентичность (связь категорий «Комсомольск-на-Амуре» и «комсомольчанин» с другими явлениями и категорией «Я»).

По мнению Г.М. Андреевой, у человека в процессе жизни формируется специфическая идентичность с окружающей средой, которую на уровне обыденной психологии принято называть «жизненной средой», к которой можно отнести географический район его проживания, тип поселения (город или деревня), природные и климатические характеристики своей местности и многое другое [1]. И.Ю. Кузнецов и С.А Кузнецова данный феномен называют «территориальное самоопределение» [12], И.С. Самошкина - «территориальная идентичность» [22].

Корреляционный анализ показал, что молодежь, не определившаяся с местом жительства («прагматики»), по содержанию выделяет следующие сферы жизнедеятельности (рис. 1): коммуникативную (друзья, мы, семья) и профессиональную (профессиональная карьера, работа).

Межличностные отношения данных респондентов являются самыми представленными, но данная сфера для респондента является биполярной: с одной стороны, она включает друзей, ингруппу 
«Мы» и семью, явно значимых и референтных других, с другой стороны, обозначенные группы опосредованно связаны через отрицательную корреляцию с категорией «Настоящее». Скорее всего, этот факт указывает на то, что сложившиеся межличностные отношения являются важными и значимыми, но в настоящем они не устраивают самого субъекта.

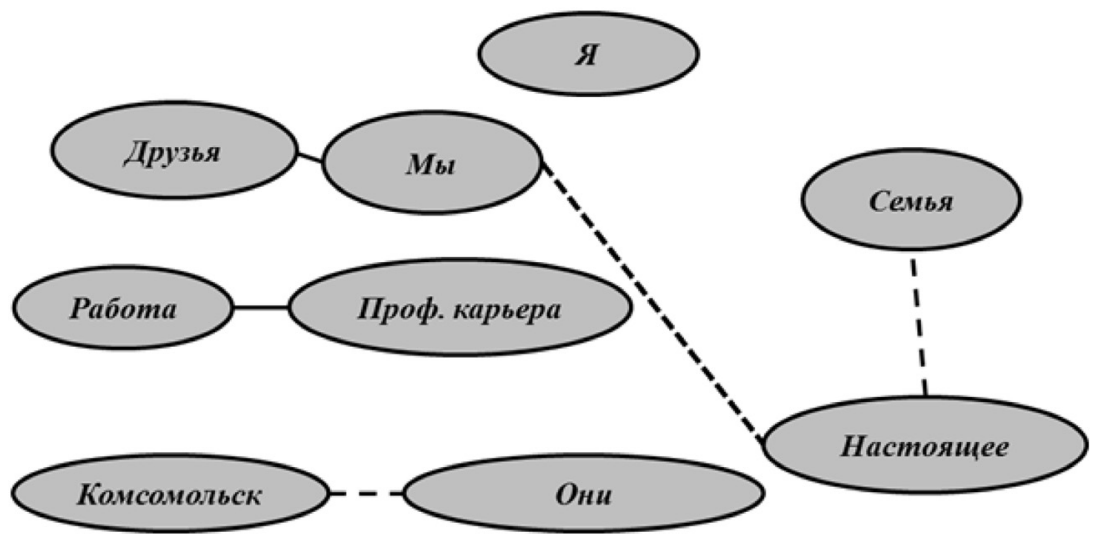

Условные обозначения: ----отрицательная связь; - положительная связь

Рис. 1. Социально-психологическое пространство города Комсомольска-на-Амуре в представлении молодёжи, неопределившейся с местом проживания

Сфера профессионального саморазвития представлена только категориями работа и профессиональная карьера, что указывает на значимость данной сферы, а отсутствие связи с другими категориями - на ее неопределенность (отсутствует связь с местом и временем и не представлена стратегия профессионального развития).

Территория проживания (Комсомольск-на-Амуре) отрицательно связана с аутгруппой «Они», субъект («Я») дистанцирован и не идентифицирует себя с городом проживания и его жителями, что указывает на отсутствие территориальной идентичности.

В целом анализ показал, что социально-психологическое пространство города Комсомольска-на-Амуре для неопределившейся молодежи рассматривается как разреженное, плохо структуриро- 
ванное, неэффективное для самореализации и саморазвития в настоящем и будущем. Необходимо отметить, что отношение к городу Комсомольску-на-Амуре как к месту проживания неоднозначное.

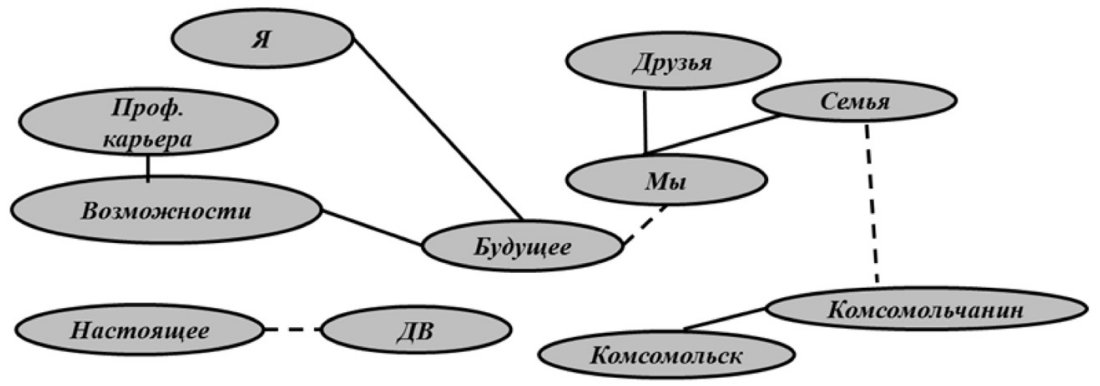

Условные обозначения: ----отрицательная связь; положительная связь

Рис. 2. Социально-психологическое пространство города Комсомольска-на-Амуре в представлении молодёжи с выраженными миграционными намерениями

В социально-психологическом пространстве молодежи, стремящейся поменять место жительства («антипатриоты»), выделяются те же сферы жизнедеятельности (коммуникативная, профессиональная, временная и территориальная), но они имеют другую структуру (рис. 2). Центральной категорией в данной структуре является временная характеристика «Будущее» (имеющая наибольшее число значимых связей), которая, с одной стороны, имеет положительную связь с категорией «Я» и с профессиональной самореализацией, а с другой стороны, отрицательно связана со значимыми другими: «Мы» (семья, друзья), горожанами и городом в целом. Данный блок указывает на стремление субъекта в будущем к реализации возможностей и построению профессиональной карьеры, а межличностные отношения, значимые другие и территория проживания воспринимаются респондентами как сдерживающий фактор, который мешает реализовать задуманное. Настоящее отрицательно связано с регионом проживания и не связано с самим субъектом.

В целом анализ показал, что социально-психологическое пространство города Комсомольска-на-Амуре для молодежи, имеющей миграционные намерения, рассматривается как неэффективное для 
самореализации и саморазвития в настоящем и будущем, поэтому даже наличие значимых других в месте проживания воспринимается как препятствие (что отражается в значимо более негативном отношении к группе «Мы»), которое необходимо преодолеть. Данная группа молодежи не рассматривает г. Комсомольск-на-Амуре и в целом Дальневосточный регион как территорию жизнедеятельности.

У молодежи, желающей жить в городе («патриоты»), в социально-психологическом пространстве не выделяются отдельные сферы жизнедеятельности (рис. 3). Вся структура социально-психологического пространства связана в единый смысловой блок. Центральной категорией в данной структуре является «Профессиональная карьера», которая связывает саморазвитие, работу, возможности, образование, настоящее и будущее. Данная сфера определяет вектор активности субъекта в профессиональном саморазвитии: образование - работа - профессиональное саморазвитие и возможности.

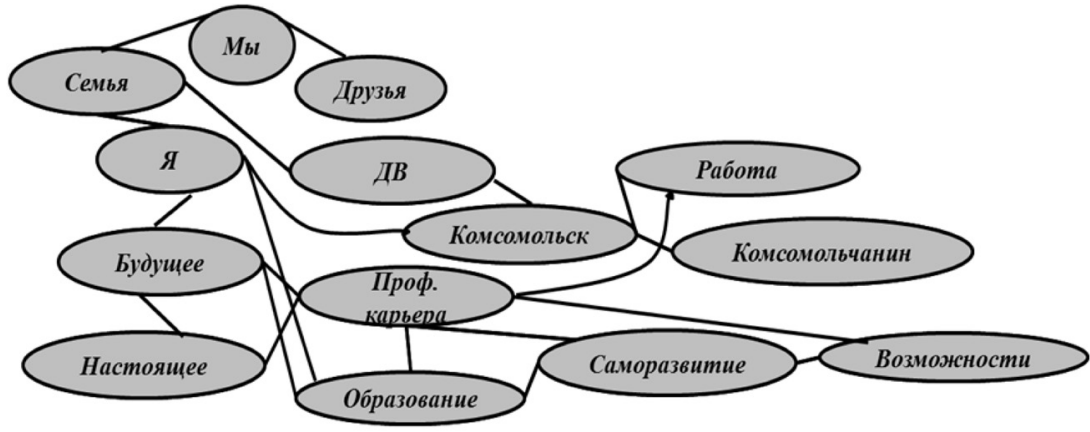

Услоеные обозначения: ----отрицательная сөязь; - положительная связь

Рис. 3. Социально-психологическое пространство города Комсомольска-на-Амуре в представлении молодёжи, которая хочет остаться в городе

Вторым структурным центром является категория «Я», которая соединяет межличностные отношения, территорию проживания и временные перспективы. Данный блок указывает на стремление субъекта в настоящем и будущем к профессиональной и личностной самореализации на территории проживания. Связь категории «Я» с городом Комсомольском-на-Амуре говорит о сформированной 
территориальной идентичности. Таким образом, социально-психологическое пространство города Комсомольска-на-Амуре для этой группы респондентов рассматривается как эффективное для самореализации и саморазвития в настоящем и будущем.

Обобщая полученные данные, можно утверждать, что для молодежи, стремящейся уехать из города, характерным является негативное отношение к региону, его населению и своей настоящей жизни. Город рассматривается ими как неэффективное социально-психологическое пространство для жизни, что и определяет их миграционную активность. Для молодежи, желающей остаться в регионе, город воспринимается как эффективное пространство для жизнедеятельности, что оказывает сдерживающее воздействие. Необходимо отметить, что в целом все оцениваемые элементы пространства оказываются для них более позитивно окрашенными, в том числе их настоящее, место проживания и население города. Полученные результаты указывают на позитивную территориальную идентичность данной группы молодежи.

\section{Заключение}

Наше исследование было направлено на изучение специфики социально-психологического пространства города Комсомольска-на-Амуре у молодежи с разными миграционными намерениями. В исследовании было обнаружено, что большая часть молодежи (52\%) не определилась с местом проживания, 26\% молодых людей не собираются менять место жительства, 22\% респондентов намерены уехать из города.

Нами выявлено, что социально-психологическое пространство города Комсомольска-на-Амуре имеет содержательные и структурные особенности у молодежи с разными миграционными намерениями.

Интенсивность общения в реальной жизни у всех выделенных групп молодежи одинаковая, однако, молодежь, которая хочет уехать из города, значимо интенсивнее общается в социальных сетях. Молодежь с выраженными миграционными намерениями более негативно относится к Дальневосточному региону, его населению и своей настоящей жизни. Молодежь, желающая остаться в регионе, 
позитивно относится к своей настоящей жизни, месту проживания и населению города.

Анализ социально-психологического пространства города Комсомольска-на-Амуре для молодежи с разными миграционными намерениями показал, что для неопределившейся и желающей уехать из города молодежи данное пространство рассматривается как неэффективное для самореализации и саморазвития в настоящем и будущем. Респонденты обеих групп не идентифицируют себя с территорией проживания. Необходимо отметить, что те, кто хочет уехать, не связывают свое будущее и возможности профессионального саморазвития с городом, но видят возможности самореализации в будущем. Молодежь с неопределенными миграционными намерениями дистанцирует свое «Я» от всех других объектов социальнопсихологического пространства.

Молодежь, которая хочет остаться в городе, рассматривает его как эффективное пространство для самореализации и саморазвития в настоящем и будущем, имеет сформированную территориальную идентичность.

Учитывая существенную долю «прагматиков» (готовых уехать при определенных условиях) в составе молодёжи г. Комсомольскана-Амуре, можно говорить о необходимости формирования территориальной идентичности, что невозможно без создания эффективного пространства для самореализации и саморазвития молодежи.

Информация о конфликте интересов. Авторы заявляют об отсутствии конфликта интересов.

Информация о спонсорстве. Работа выполнена при финансовой поддержке Министерства образования и науки РФ, проект № №142/2018Д «Социальные и психологические факторы миграции молодежи города Комсомольска-на-Амуре».

\section{Список литературы}

1. Андреева Г.М. Психология социального познания. М.: Аспект Пресс, 2000. 288 c. 
2. Гуревич А.М. Мотивация эмиграции. СПб.: Речь, 2005. 272 с.

3. Журавлев А.Л., Купрейченко А.Б. Психологическое и социальнопсихологическое пространство личности: теоретические основания исследования // Знание. Понимание. Умение. 2012. № 2. С. 10-18.

4. Журавлев А.Л., Купрейченко А.Б. Самоопределение, адаптация и социализация: соотношение и место в системе социально-психологических понятий // Психология адаптации и социальная среда: современные подходы, проблемы, перспективы / Отв. ред. Л.Г. Дикая, А.Л. Журавлев. М.: Изд-во «Институт психологии РАН», 2007. С. 62-95.

5. Зайончковская Ж.А. Демографическая ситуация и расселение. М.: Наука, 1991. 130 с.

6. Зайончковская Ж.А. Миграции и демографическое будущее Сибири и Дальнего Востока // Россия и ее регионы в XX веке: территория - расселение - миграции / Под ред. О. Глезер и П. Поляна. М.: ОГИ, 2005. С. 479-490.

7. Зайончковская Ж.А., Ноздрина Н.А. Миграционная подвижность населения России и ее территориальная дифференциация (по результатам обследования в 10 городах) // Демографические перспективы России. Материалы международной научно-практической конференции «Демографическое будущее России: проблемы и пути решения» (Москва, 19-21 сентября 2008 г.) / Редакторы-составители С.В. Рязанцев и Р.В. Маньшин. М.: Academia, 2008. С. 397-402.

8. Зайончковская Ж.А., Ноздрина Н.Н. Миграционный опыт населения региональных центров России (на примере социального опроса в 10 городах) // Проблемы прогнозирования. 2008. № 4. С. 98-111.

9. Карачурина Л.Б., Мкртчян Н.В. Изменение численности населения административных районов и городов России (1989-2010 гг.): центро-периферийные соотношения // Вопросы географии. География населения и социальная география / Ред. А.И. Алексеев, А.А. Ткаченко. М.: Изд. дом «Кодекс», 2013. С. 82-107.

10. Карачурина Л.Б., Мкртчян Н.В. Миграционная подвижность молодежи и сдвиги в возрастной структуре населения городов и районов России (1989-2002) // Географическое положение и территориаль- 
ные структуры: памяти И. М. Маергойза / Сост. П.М. Полян, А.И. Трейвиш. М.: «Новый хронограф», 2012. С. 688-707.

11. Корель Л.В. Перемещения населения между городом и селом в условиях урбанизации. Новосибирск: Наука, 1982. 192 с.

12. Кузнецов И.Ю., Кузнецова С.А. Самоопределение личности на жизненном пути. Магадан: Кордис, 2003. 216 с.

13. Лебедева Н.М. Социальная психология этнической миграции. М.: Российская академия наук, Ин-т этнологии и антропологии им. Н.Н. Миклухо-Маклая, 1993. 196 с.

14. Марцинковская Т.Д. Социальное пространство: теоретико-эмпирический анализ // Психологические исследования. 2013. № 6 (30). URL: http://psystudy.ru/index.php/eng/2013v6n30e/864-martsinkovskaya30e. html (дата обращения: 14.07.2018).

15. Методика оценки сформированности гражданской идентичности коллективного субъекта. Свидетельство о регистрации НОУ-ХАУ №2016-01.7 / Шмакова В.А., Опевалова Е.В., Махова И.Ю., Яремчук С.В., Бакина А.В. Комсомольск-на-Амуре: ФГБОУ ВО «АмГПГУ», 2016.

16. Миграция и демографический кризис в России / Под ред. Ж.А. Зайончковской, Е.В. Тюрюкановой. М.: МАКС Пресс, 2010. 112 с.

17. Мкртчян Н.В. Миграция в России: западный дрейф // Информационный бюллетень Центра демографии и экологии ИНП РАН. 2004. № 87.

18. Мунгалов В.Н. Психологическое пространство человека: содержание и объяснительные возможности понятия // Известия Иркутской государственной экономической академии. 2013. № 3. С. 140-143.

19. Павленко В.Н. Аккультурационные стратегии и модели трансформации идентичности у мигрантов // Психология беженцев и вынужденных переселенцев: опыт исследований и практической работы / Под ред. Г.У. Солдатовой. М.: Изд-во «Смысл», 2001. С. 25-39.

20. Пригожин И., Стенгерс И. Порядок из хаоса. Новый диалог человека с природой. М.: Эдиториал УРСС, 2000. 312 с.

21. Рыбаковский Л.Л. Миграция населения (вопросы теории). М.: ИСПИ PAH, 2003. 238 c. 
22. Самошкина И.С. Территориальная идентичность как социальнопсихологический феномен: Автореф. дисс. ... канд. психол. наук. M., 2008. 29 c.

23. Сигарева Е.П., Сивоплясова С.Ю. Некоторые аспекты миграционной мотивации российской молодежи // Народонаселение. 2014. № 2. С. 65-71.

24. Трубецкой В. Хронические болезни Дальнего Востока. URL: https:// www.vesti.ru/doc.html?id=114823\&tid=41393 (дата обращения: 14.07.2018).

25.Шукова Г.В. Особенности социально-психологического пространства молодых специалистов-практических психологов // Психологические исследования. 2014. 7 (33). URL: http:// psystudy.ru/num/2014v7n33/938-shukova33.html (дата обращения: 14.07.2018).

26. Achievement, power, and affiliation motives as clues to (e)migration desires: A four-countries comparison / Boneva B.S., Frieze I.H., Ferligoj A., Jarosova E., Pauknerova D., Orgocka A. // European Psychologist. 1998. vol. 3(4), pp. 247-254.

27. Festinger L. A theory of social comparison processes // Human Relations. 1954. № 7, pp. 117-140. Festinger L. Human Relations, 1954, vol. 7, pp. 117-140.

28.Frieze I.H., Hansen S.B., Boneva B. The migrant personality and college students' plans for geographic mobility // Journal of Environmental Psychology. 2006. vol. 26, pp. 170-177. doi: 10.1016/j. jenvp.2006.05.001

29. Hidalgo M.C., Hernandez B. Place attachment: Conceptual and empirical questions // Journal of Environmental Psychology. 2001. vol. 21(3), pp. 273-281. doi: 10.1006/jevp.2001.0221

30. International Migration Report 2017: Highlights. New York: United Nations, 2017. $30 \mathrm{p}$.

31. Mak A.S. Career relocation issues and repatriation dilemma: skilled Hong Kong immigrants to Australia // Experiences of transnational Chinese migrants in the Asia-Pacific / Eds. D. Ip, R. Hibbins and W.H. Chui. New York: Nova Science publishers, 2006, pp. 103-116. 
32. Manchin M., Orazbayev S. Social networks and the intention to migrate. Centro Studi Luca d'Agliano // Development Studies Working Paper. 2016. vol. 409, pp. 1-50. doi: 10.2139/ssrn.2974097

33. Neto F., Silva C. Intention of emigrating among Portuguese adolescents: a study of associations // Migration: A European Journal of International Migration and Ethnic Relations. 1995. vol. 25, pp. 51-78.

34. Reasons for leaving home: Comparing predictors of wanting to migrate and travel in Croatian undergraduates / Li M., Frieze, I.H., Horvat, J., Mijoč, J., Olson, J. // Migracijske Teme (Migration and Ethic Themes). 2012. vol. 28 (1), pp. 7-27.

35. Roman M., Vasilescu M.D. Explaining the migration intentions of Romanian youth: Are teenagers different? // Romanian Statistical Review. 2016. vol. 64 (4), pp. 69-86.

36. Skilled German migrants and their motives for migration within Europe / Verwiebe R., Mau S., Seidel N., Kathmann T. // Journal of International Migration and Integration. 2010. vol. 11 (3), pp. 273-293. doi: 10.1007/ s12134-010-0141-9

37. Theodori A.E., Theodori, G. L. The influences of community attachment, sense of community, and educational aspirations upon the migration intentions of rural youth in Texas // Community Development. 2015. vol. 46 (4). P. 380-391. doi: 10.1080/15575330.2015.1062035

38. Todaro M.P. Internal migration in developing countries: A survey // Population and Economic Change in Developing Countries Volume / Ed. A. Easterlin. Chicago: University of Chicago Press, 1980, pp. 361-402.

39. Wiskow C. Health worker migration flows in Europe: overview and case studies in selected CEE countries - Romania, Czech Republic, Serbia and Croatia. Geneva: International Labour Organization, 2006. $114 \mathrm{p}$.

\section{References}

1. Andreeva G.M. Psihologija social'nogo poznanija [Psychology of social cognition]. M.: Aspekt Press, 2000, 288 p.

2. Gurevich A.M. Motivacija jemigracii [Motivation for emigration]. SPb.: Rech', 2005, 272 p. 
3. Zhuravlev A.L., Kuprejchenko A.B. Znanie. Ponimanie. Umenie [Knowledge. Understanding. Skill], 2012, no. 2, pp. 10-18.

4. Zhuravlev A.L., Kuprejchenko A.B. Psihologija adaptacii i social'naja sreda: sovremennye podhody, problemy, perspektivy [Psychology of adaptation and social environment: modern approaches, problems, prospects]. M.: Izd-vo «Institut psihologii RAN», 2007, pp. 62-95.

5. Zajonchkovskaja Zh.A. Demograficheskaja situacija i rasselenie [Demographic situation and resettlement]. M.: Nauka, 1991, 130 p.

6. Zajonchkovskaja Zh.A. Rossija i ee regiony v XX veke: territorija-rasselenie - migracii [Russia and its regions in the 20th century: territory-resettlement-migration]. Moscow: Publ. OGI, 2005, pp. 479-490.

7. Zajonchkovskaja Zh.A., Nozdrina N.A. Demograficheskie perspektivy Rossii. Materialy mezhdunarodnoj nauchno-prakticheskoj konferencii "Demograficheskoe budushhee Rossii: problemy i puti reshenija" (Moskva, 19-21 sentjabrja 2008 g.) [Demographic prospects of Russia. Materials of the International Scientific and Practical Conference "The Demographic Future of Russia: Problems and Solutions" (Moscow, September 19-21, 2008)]. M.: Academia, 2008, pp. 397-402.

8. Zajonchkovskaja Zh.A., Nozdrina N.N. Problemy prognozirovanija [Studies on Russian Economic Development], 2008, no. 4, pp. 98-111.

9. Karachurina L.B., Mkrtchjan N.V. Voprosy geografii. Geografija naselenija i social'naja geografija [Questions of geography. Geography of the population and social geography]. M.: Izd. dom «Kodeks», 2013, pp. 82-107.

10. Karachurina L.B., Mkrtchjan N.V. Geograficheskoe polozhenie i territorial'nye struktury: pamjati I. M. Maergojza [Geographical location and territorial structures: the memory of I.M. Maergoiz]. M.: «Novyj hronograf», 2012, pp. 688-707.

11. Korel L.V. Peremeshchenie naseleniya mezhdu gorodom i selom v usloviyakh urbanizatsii [Population movements between urban and rural areas in terms of urbanization]. Novosibirsk: Nauka Publ., 1982, 192 p.

12. Kuznecov I.Ju., Kuznecova S.A. Samoopredelenie lichnosti na zhiznennom puti [Self-determination of the person on the path of life]. Magadan: Kordis, 2003, 216 p. 
13. Lebedeva N.M. Social'naja psihologija jetnicheskoj migracii [Social psychology of ethnic migration]. M.: Rossijskaja akademija nauk, 1993, $196 \mathrm{p}$.

14. Martsinkovskaya T.D. Psikhologicheskie Issledovaniya [Psychological Studies], 2013, vol. 6, no. 30. http://psystudy.ru/index.php/ eng/2013v6n30e/864-martsinkovskaya30e.html (accessed July 14, 2018).

15. Shmakova V.A., Opevalova E.V., Mahova I.Ju., Jaremtchuk S.V., Bakina A.V. Metodika ocenki sformirovannosti grazhdanskoj identichnosti kollektivnogo sub\#ekta [Assessment of civil identity of collective subject]. Komsomol'sk-na-Amure: FGBOU VO «AmGPGU», 2016.

16.Zajonchkovskaja Zh.A., Tjurjukanova E.V. (Eds.) Migracija i demograficheskij krizis $v$ Rossii [Migration and demographic crisis in Russia]. M.: MAKS Press, 2010, 112 p.

17. Mkrtchjan N.V. Informacionnyj bjulleten' Centra demografii i jekologii INP RAN [Information Bulletin of the Center for Demography and Ecology of Institute of Economic Forecasting, RAS], 2004, no. 87.

18. Mungalov V.N. Izvestija Irkutskoj gosudarstvennoj jekonomicheskoj akademii [BULLETIN of Baikal State University], 2013, no. 3, pp. 140 143.

19. Pavlenko V.N. Psihologija bezhencev $i$ vynuzhdennyh pereselencev: opyt issledovanij i prakticheskoj raboty [Psychology of refugees and internally displaced persons: experience of research and practical work]. M.: «Smysl», 2001, pp. 25-39.

20.Prigozhin I., Stengers I. Porjadok iz haosa. Novyj dialog cheloveka s prirodoj [Order out of chaos: Man's new dialogue with nature]. M.: Jeditorial URSS, 2000, 312 p.

21. Rybakovskij L.L. Migracija naselenija (voprosy teorii) [Migration of population (theory issues)]. M.: ISPI RAN, 2003, $238 \mathrm{p}$.

22. Samoshkina I.S. Territorial'naja identichnost' kak social'no-psihologicheskij fenomen [Territorial identity as a socio-psychological phenomenon]. M., 2008, 29 p.

23. Sigareva E.P., Sivopljasova S.Yu. Narodonaselenie [Population], 2014, no. 2 , pp. $65-71$. 
24. Trubeckoj V. Hronicheskie bolezni Dal'nego Vostoka [Chronic diseases of the Far East Russia]. https://www.vesti.ru/doc.html?id=114823\&tid=41393 (accessed July 14, 2018).

25. Shukova G.V. Psikhologicheskie Issledovaniya [Psychological Studies], 2014, vol. 7, no. 33. http://psystudy.ru/num/2014v7n33/938-shukova33. html (accessed July 14, 2018).

26. Boneva B.S., Frieze I.H., Ferligoj A., Jarosova E., Pauknerova D., Orgocka A. European Psychologist, 1998, vol. 3 (4), pp. 247-254.

27. Festinger L. Human Relations, 1954, vol. 7, pp. 117-140.

28. Frieze I.H., Hansen S.B., Boneva B. Journal of Environmental Psychology, 2006, vol. 26, pp. 170-177. doi: 10.1016/j.jenvp.2006.05.001

29. Hidalgo M.C., Hernandez B. Journal of Environmental Psychology, 2001, vol. 21 (3), pp. 273-281. doi: 10.1006/jevp.2001.0221

30.International Migration Report 2017: Highlights. New York: United Nations, 2017, $30 \mathrm{p}$.

31. Mak A.S. Experiences of transnational Chinese migrants in the Asia-Pacific. New York: Nova Science publishers, 2006, pp. 103-116.

32. Manchin M., Orazbayev S. Development Studies Working Paper, 2016, vol. 409, pp. 1-50. doi: 10.2139/ssrn.2974097

33. Neto F., Silva C. Migration: A European Journal of International Migration and Ethnic Relations, 1995, vol. 25, pp. 51-78.

34. Li M., Frieze, I.H., Horvat, J., Mijoč, J., Olson, J. Migracijske Teme (Migration and Ethic Themes), 2012, vol. 28 (1), pp. 7-27.

35.Roman M., Vasilescu M.D. Romanian Statistical Review, 2016, vol. 64 (4), pp. 69-86.

36. Verwiebe R., Mau S., Seidel N., Kathmann T. Journal of International Migration and Integration, 2010, vol. 11 (3), pp. 273-293. doi: 10.1007/ s12134-010-0141-9

37. Theodori A.E., Theodori G. L. Community Development, 2015, vol. 46 (4), pp. 380-391. doi: 10.1080/15575330.2015.1062035

38. Todaro M.P. Population and Economic Change in Developing Countries Volume. Chicago: University of Chicago Press, 1980, pp. 361-402.

39. Wiskow C. Health worker migration flows in Europe: overview and case studies in selected CEE countries - Romania, Czech Republic, 
Serbia and Croatia. Geneva: International Labour Organization, 2006, $114 \mathrm{p}$.

\section{ДАННЫЕ ОБ АВТОРАХ}

Бакина Анна Владимировна, доцент кафедры психологии образования, кандидат психологических наук, доцент Амурский гуманитарно-педагогический государственный университет

ул. Кирова, 17/2, г. Комсомольск-на-Амуре, Хабаровский край, 681000, Российская Федеращия bakina_anna@mail.ru

Орлова Ольга Александровна, доцент кафедры психологии образования, кандидат психологических наук, доцент Амурский гуманитарно-педагогический государственньй университет

ул. Кирова, 17/2, г. Комсомольск-на-Амуре, Хабаровский край, 681000, Российская Федерациия olga_shishmareva@mail.ru

Яремчук Светлана Владимировна, доцент кафедры психологии образования, кандидат психологических наук, доцент Амурский гуманитарно-педагогический государственный университет

ул. Кирова, 17/2, г. Комсомольск-на-Амуре, Хабаровский край, 681000, Российская Федеращия

svj@rambler.ru

\section{DATA ABOUT THE AUTHORS}

Bakina Anna Vladimirovna, Associate Professor at the Department of Education Psychology, Ph.D. in Psychology, Associate Professor Amur State University of Humanities and Pedagogy 17/2, Kirova St., Komsomolsk-on-Amur, Khabarovsk Krai, 681000 , Russian Federation 
bakina_anna@mail.ru

SPIN-code: 7261-1748

ORCID: 0000-0002-6772-3743

Orlova Olga Aleksandrovna, Associate Professor at the Department of Education Psychology, Ph.D. in Psychology, Associate Professor Amur State University of Humanities and Pedagogy

17/2, Kirova St., Komsomolsk-on-Amur, Khabarovsk Krai, 681000, Russian Federation

olga_shishmareva@mail.ru

SPIN-code: 3095-8858

ORCID: 0000-0002-9080-0129

Yaremtchuk Svetlana Vladimirovna, Associate Professor at the Department of Education Psychology, Ph.D. in Psychology, Associate Professor

Amur State University of Humanities and Pedagogy

17/2, Kirova St., Komsomolsk-on-Amur, Khabarovsk Krai, 681000, Russian Federation

svj@rambler.ru

SPIN-code: 1673-8024

ORCID: 0000-0003-1036-6826

ResearcherID: A-3599-2017

Scopus Author ID: 56111955900 